\title{
Vocational versus general education: Employment and earnings over the life course in Switzerland
}

\author{
Maïlys Korber, Daniel Oesch* \\ Life Course and Inequality Research Centre (LINES), LIVES - Swiss National Centre of Competence in Research, University of Lausanne, 1015 Lausanne, Switzerland
}

\section{A R T I C L E I N F O}

\section{Keywords:}

Vocational training

Wages

Education

Employment

Careers

Switzerland

\begin{abstract}
A B S T R A C T
After the Great Recession, vocational training was strongly promoted across the OECD as a measure to fight youth unemployment. Vocational degrees may give workers a head start in the labour market. However, these degrees may also become obsolete sooner and leave older workers vulnerable to technological change. We thus compare the evolution of employment and earnings over the life course for holders of vocational and general education at the upper-secondary level. We use a cohort design for Switzerland, the OECD country with the highest share of youth undertaking vocational education. Based on the Swiss Labour Force Survey 1991-2014 and the Swiss Household Panel 1999-2015, our results show that employment prospects remain as good for vocational as for general education over the second half of workers' careers. However, vocational education is associated with substantially lower earnings once workers enter their thirties, and this disadvantage is larger among women than men. While vocational degrees protect against unemployment, they come at the cost of flat earnings curves over the life course.
\end{abstract}

\section{Introduction}

In the wake of the Great Recession, vocational education has become a widely advocated policy solution to staggering rates of youth unemployment. A tighter link between the skills provided by vocational training and the skills demanded by employers should ease the transition from school to work. The OECD (2010) propagated Germany and Switzerland's apprenticeship systems in particular, which combine learning in the workplace with lessons at vocational schools. Consequently, government delegations flock to Berlin and Bern in order to study - and possibly emulate - these systems of vocational education and training (VET). ${ }^{1}$

In the short run, vocational education and particularly apprenticeships have several attractive features. As employers contribute to the development of degrees and teaching curricula, the vocational skills obtained are immediately instrumental in the labour market. This helps young people to transit into the world of work and leads to lower youth unemployment (Shavit \& Müller, 1998). However, while VET may enable young people to find a good match at the beginning of their career, it may leave older workers vulnerable to technological change and shifts in the occupational structure. Over the life course, job-specific skills learnt in vocational training may become obsolete at a faster rate than general skills learnt in academic curricula. Accordingly, the advantages of VET in smoothing the entry into the labour market may have to be weighed against potential disadvantages later on in the career.

However, there may be no reversal of fortunes over the life course between holders of vocational and holders of general education - because what really counts may be getting off to a good start. The idea is that initial experiences in the labour market crucially shape later working life. As VET facilitates youth integration into the workplace, it may lay the foundation for a successful career. On the contrary, prolonged youth unemployment may have a scarring effect on subsequent work experiences (Gangl, 2006) - and securing a stable job may be more difficult for young people with general schooling than apprenticeships.

Several influential studies have recently taken up this issue, notably Forster, Bol, and Van de Werfhorst (2016) and Hanushek, Schwerdt, Woessmann, and Zhang (2017). They examine the age-employment curve associated with different types of education and find a higher employment probability for VET than general education at the start of workers' career, but a reversing pattern in later life. However, both studies use a cross-sectional survey on adult competencies and thus rely on a single measurement in time. This forces the authors to interpret the

\footnotetext{
* Corresponding author.

E-mail addresses: Mailys.korber@unil.ch (M. Korber), daniel.oesch@unil.ch (D. Oesch).

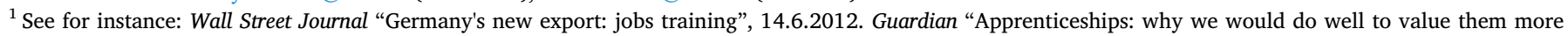
highly", 27.8.2012. The Economist "Ein neuer Deal? Germany's vaunted dual-education system is its latest export hit", 1.6.2013.
} 
employment situation of a given age group in the year of the survey as an early or late career outcome that is valid for all age groups, regardless of the birth cohort. This assumption is valid if the social and economic context in which different cohorts made their educational choices and entered the labour market remained constant between the 1950s and 2000s. Given the extent of educational expansion, technological progress and occupational upgrading over the period under study, this seems a strong assumption.

Consequently, we contribute to this debate by adopting a life course perspective and focussing on a single birth cohort. We use data that cover almost three decades and allow us to compare how the employment prospects and earnings vary by age for a cohort of individuals born between the mid-1950 and mid-1960s who either obtained an upper-secondary vocational or general degree as their highest education. $^{2}$

Our analysis focuses on Switzerland, the OECD country with the highest share of youth who attend a work-based (dual) VET course after the end of compulsory school: 60 per cent in 2011. If VET pays off anywhere, then it should be in Switzerland's apprenticeship system, which trains for both blue-collar and white-collar occupations, leads to nationally standardised skill certificates and enjoys broad support from employers (Hoffman \& Schwartz, 2015).

We use the Swiss Labour Force Survey, years 1991-2014, to construct a pseudo cohort of individuals observed in successive years. For greater robustness, we follow the practice of "identical analysis of parallel data" (Firebaugh, 2008) and replicate our analysis with longitudinal data from the Swiss Household Panel (1999-2015).

In the next section, we contrast three expectations on the long-term returns to vocational education. We then present Switzerland's educational system and discuss our data, measures and model. The results section compares the age-earnings and age-employment curves for workers with upper-secondary vocational and general education. We conclude by discussing the policy implications of our findings.

\section{Vocational training and the life course}

When evaluating the merits of vocational education, pundits commonly resort to the youth unemployment rate as the key indicator. In the same vein, a large body of research compares different educational tracks by focusing on labour market entry (e.g. Müller \& Gangl, 2003; Shavit \& Müller, 1998). Yet information on the first few years of workers' trajectory leaves us with only a partial picture of their career. VET may provide useful skills for an occupational field at the time of training and thereby ease entry into the labour market. Yet it is an open question as to whether these same skills are still valuable when workers are in their mid-forties and older. On this question, we distinguish three competing expectations: (i) cumulative advantage in favour of vocational education, (ii) reversal of fortunes in favour of general education, (iii) identical outcomes for general and vocational education once heterogeneity is taken into account.

\subsection{Cumulative advantage over the life course}

Work-based VET has the key advantage of integrating practice into the learning process and thus ensuring close correspondence between the acquired skills and the actual requirements of firms. Thereby, it smooths the school-to-work transition (Wolter \& Ryan, 2011: 523). These advantages should be particularly marked in countries where VET is occupationally specific, offering specialised training for

\footnotetext{
${ }^{2}$ Our comparison thus focuses on individuals who hold a full upper-secondary vocational certificate or a full upper-secondary general maturity certificate (ISCED 3a for general and ISCED 3b for vocational or categories 2c_voc and $2 c$ sen according to the CASMIN classification). In our cohort of interest, this is the highest level of education of 54 per cent.
}

hundreds of detailed occupations and taking place in a dual system that combines school- and work-based learning. If, in addition, the vocational education system is standardised and delivers national qualifications that are recognised by employers, a vocational degree likely gives young workers a head start in the labour market (Bol \& van de Werfhorst, 2011; Grønning, Kriesi, \& Sacchi, 2018).

Countries with VET systems that meet these criteria such as Austria, Germany or Switzerland have particularly low youth unemployment rates (OECD, 2010: 12, 170). Furthermore, it is not only on the country level, but also within these countries that VET stands out as easing the transition to work. Based on the German Socio-Economic Panel (SOEP) 1984-1990, Winkelmann (1996: 666) finds that the unemployment rate right after the end of education is 23 percentage points lower for apprenticeship graduates than for university graduates. Apprentices obtain early on workplace experience that facilitates the transition to a job. More importantly, for many of them the search issue does not arise in the first place. One year after graduation, 36 per cent of Swiss apprentices and over 50 per cent of German apprentices still work for their training firm (Dionisius et al., 2009: 16; Protsch \& Solga, 2015: 522).

Avoiding a prolonged period of youth unemployment may be crucial for the subsequent career as an early failure in the labour market possibly triggers a mechanism of cumulative disadvantage. Unemployment early on in the career may leave scars on workers because it reduces their human capital, confidence and psychological readiness for work, and may thus make them less attractive to prospective employers (DiPrete \& Eirich, 2006: 287). Life history data from the Netherlands (Luijkx \& Wolbers, 2009) and European data from SHARELIFE (Brandt \& Hank, 2014: 739) suggest that non-employment early in working life indeed has a scarring effect on the subsequent career. These arguments lead to a first expectation:

Upper-secondary vocational education should ease the entry into the labour market and thus facilitate the advancement of a career, leading to higher employment participation and earnings over the life course than upper-secondary general education.

\subsection{Reversal of fortunes over the life course}

A second expectation derives from the argument that vocational training provides specific skills, whereas academic schooling produces general skills (Becker, 1964). In this view, vocational training programmes that provide students with a narrow and specific set of skills should lead to a better initial match in the labour market and to higher starting wages. This is the reason why VET enjoys broad public support in German-speaking countries: a practical education from which young people graduate knowing a specific trade. However, it is also the reason why the U.S. has largely eliminated vocational education as a separate track in secondary schools: specific skills linked to a trade become outdated too rapidly (Hanushek et al., 2017).

While the specificity of vocational skills should not be overestimated - they are clearly transferable beyond single firms (Müller \& Schweri, 2015; Winkelmann, 1996: 668) - vocational degrees are closely linked to single occupations. The Swiss VET system offers schoolleavers apprenticeships in 230 occupations, the German VET system in 328 occupations. Specialising in a given occupation may be valuable at a given moment in time, but carries the risk that the skills specific to this occupation are obsolete one or two decades later. Newspaper typesetters and switchboard operators are two occupations that have disappeared, travel agents and postal clerks two occupations that may follow them in a near future (Oesch, 2013).

VET's strong focus on practical skills may come at the cost of neglecting general skills. In Germany and Switzerland, apprentices typically spend one to two days per week at vocational schools and three to four days in the workplace where they engage in on-the-job training. One to two days of schooling per week do not allow much instruction 
time for general skills such as literacy, numeracy and foreign languages - all the less so because half of instruction time goes to subjects related to apprentices' vocational skills (OECD, 2013: 82).

While general skills may not prepare well for entry into the labour market, they are probably more adaptive and transferable, thereby providing a stronger basis for further learning. Workers with general skills may thus be better equipped to respond to technological change and to switch occupations more easily. In comparison, a vocational degree may have a shorter half-life over the career. The initial labour market advantage of vocational over general education may therefore decrease, and possibly reverse, with age.

Based on data from the International Adult Literacy Survey (IALS), Hanushek et al. (2017) find that people with vocational qualifications under 40 benefit from an employment advantage, whereas people older than 40 are at a disadvantage relative to individuals with general education. The trade-off between initial employment gains from vocational education and employment losses later on seems particularly marked in Denmark, Germany and Switzerland, three typical apprenticeship countries. Forster et al. (2016) use the more recent PIAAC data and, controlling for numeracy skills, find that in terms of employment probabilities graduates from general education programmes catch up, and surpass, vocational graduates at the age of 45 for men and 36 for women - with no significant differences across countries.

The finding that vocationally trained workers suffer a faster depreciation of their skills than those with a general education is also reported by Weber (2014) for the Swiss Labour Force Survey 1998-2009 and Dearden, McIntosh, Myck, and Vignoles (2002) as well as Brunello and Rocco (2017) for Britain's National Child Development Study. These arguments lead to a second expectation:

The initial employment and earnings advantage of workers with uppersecondary vocational education turns into a disadvantage over the life course, as upper-secondary general education leads to better employment and earnings prospects over the second half of workers' careers.

\subsection{Identical outcomes}

A third expectation does not anticipate different labour market outcomes for holders of different types of education, as opposed to different levels. According to this view, both the advantages and disadvantages of holding a vocational degree are overdone. To begin with, occupational mobility is large and vocational education does not lock workers into a single occupation. In Germany, between 30 and 50 per cent of vocationally trained workers are employed in a different occupation than the one for which they were initially trained (Winkelmann, 2006: 93-94).

At the same time, if VET provides skills that are widely portable, this also leads to the question 'whether it makes sense to train as many mechanics, bakers or carpenters, if probabilities are high that they will leave their trade or never take it up in the first place' (Meyer, 2009: 36). Moreover, the initial labour market advantage of apprenticeship graduates should not be overestimated. Based on the SOEP 1984-1990, Winkelmann (1996: 671) finds that once the transition to work was made, graduates from general education were employed in jobs that were as stable as those of apprenticeship graduates. While the matching process takes longer for holders of general education, they catch up quickly over the first few years of work.

Different labour market outcomes for vocational and general education may primarily result from two sources of heterogeneity: heterogeneity of vocational degrees and population heterogeneity, that is, the selection of different people into different educational tracks. The first source relates to the widely varying quality of apprenticeships and depends on at least three dimensions: (i) firm size: larger firms provide more demanding workplace learning than small businesses; (ii) sector: the public sector tends to offer more structured VET programmes than the private sector; (iii) level of intellectual requirement: requirements vary widely across occupation and, in the case of Switzerland, are much higher in some apprenticeships such as electronics technicians and draughtsman than in others such as butchers and flooring installers (Stalder, 2011). The differences in employment prospects and earnings may thus be larger across vocational degrees than they are between vocational and general education.

The second source of heterogeneity relates to selection effects. Young people (and their parents) choose a given educational track based on their ability, social origin and interest. Since entry into general schools is often conditional on examinations, individuals with higher ability and a more privileged social background may prefer a general education to VET. Even in countries where vocational degrees enjoy broad recognition such as in Switzerland, pupils who eventually take up an apprenticeship perform worse, on average, in the PISA test than pupils who continue in a baccalaureate school (Wolter et al., 2014: 119).

If there is strong heterogeneity among individuals who take up vocational and general education, it is possible that VET pays off for some individuals but not for others. Based on the British National Child Development Study, Dearden et al. (2002: 269) find that the wage premium from vocational qualifications is twice as high for individuals having low ability in reading and mathematics than for those having high ability. The vocational route may thus be of critical importance for less academically able and more practically oriented students. By reducing the drop-out rate from high schools and increasing the share of students taking on a post-compulsory education, VET may generate important benefits (Wolter \& Ryan, 2011: 551). A comparison between holders of general and vocational degrees at the upper secondary level may not adequately capture these benefits (see Korber, 2019, chap. 3).

What does the empirical evidence tell us? Malamud and Pop-Eleches (2010) control for selection by using an educational reform in Romania in 1973 that prolonged general education for everybody and reduced the duration of VET. Despite this general increase in formal schooling, they find no difference in earnings between the pre- and post-reform cohorts. Similarly, an analysis of the National Education Longitudinal Survey for the US shows no systematic advantage of general education over vocational tracks once selection effects are controlled for (Meer, 2007). These arguments give rise to a third expectation:

If one accounts for the heterogeneity of vocational degrees and the selection into different tracks, there is no difference in employment and earnings over the life course between holders of upper-secondary vocational and general education.

\section{Institutional context, data and methods}

\subsection{Institutional context}

Our empirical analysis focusses on Switzerland, an ideal country to analyse the pay-off that general and vocational degrees have over the life course. After nine years of compulsory education (six years of primary and three years of secondary schooling), the Swiss educational system offers the choice between two main options: VET or baccalaureate school.

Two thirds of a given age cohort embark on vocational education: 60 per cent in a company-based 'dual' apprenticeship and an additional 6 per cent in a school-based form of VET (Wolter et al., 2014: 107). Apprenticeships are called dual because they combine two learning places, the training firm and the vocational school (and, additionally, include intercompany courses).

Close to a third of an age cohort remains in general education: 20 per cent enter a baccalaureate school that gives direct access to universities and close to 10 per cent go to another upper-secondary specialised school. Women are more likely than men to enrol in the uppersecondary general track, whereas men outnumber women in the vocational track. Unlike in Germany, it is unusual in Switzerland for youth 
to embark on an apprenticeship after obtaining a baccalaureate.

It takes a similar number of years to obtain a vocational degree or a baccalaureate. For most occupations, the nationally recognised VET diplomas (EFZ in German, CFC in French) require three years of training - a series of more complex occupations require four years. It thus takes, altogether, between 12 and 13 years to earn a vocational diploma as compared to $12-13$ years needed to obtain the baccalaureate (not counting the two years of pre-school or kindergarten).

Both tracks continue at the tertiary level. While a general baccalaureate degree gives access to universities, the vocational baccalaureates - introduced in the 1990s - entitle youth to study at the universities of applied science. The initial transition rates to universities or universities of applied science are much higher for graduates with general degrees (95 per cent) than vocational degrees (23 per cent) (Babel, 2018: 6). However, another third of holders of vocational degrees eventually enrol in advanced professional education and training - and thus obtain a degree at the tertiary level. The proportion of Switzerland's population with a degree from a university or university of applied science has risen rapidly over the last two decades, but is still low in international comparison (29 per cent of men and 27 of women aged 25-64 in 2014) (Federal Office of Statistics database).

\subsection{Data}

Our analysis is based on 24 annual surveys of the Swiss Labour Force Survey (SLFS), covering the years $1991-2014{ }^{3}$ We increase the robustness of our results by following the practice of "identical analysis of parallel data" (Firebaugh, 2008) and estimate the same model on an additional dataset, the Swiss Household Panel (SHP), 1999-2015 (Tillmann et al., 2016). The replication across datasets allows us to gauge the uncertainty in the results that may be due to errors commonly found in surveys linked to coverage, sampling, non-response or measurement. In addition, although the SLFS provides us with larger samples and covers a longer period, the SHP has the advantage of containing information on respondents' social origin: the education and occupation of both parents.

We impose two restrictions on the analytical sample. First, we limit our analysis of the SLFS to a pseudo-cohort of respondents born between 1954 and 1966. This specific cohort has obtained upper-secondary education and entered the Swiss labour market in the 1970s and 1980s in a period of low unemployment. This cohort is large enough to provide us with a sufficient number of observations for every single year of age between 25 and 60. In the smaller sample of the SHP, we need to construct a larger birth cohort - 1950-1979 - in order to get valid estimates for each single year of age.

Second, we limit our analyses to individuals who have no more and no less - than upper secondary education, either general or vocational. This allows us to compare individuals where only the type, but not the level or duration of education varies. In both datasets, we reduce the number of individuals who will eventually obtain a tertiary degree by limiting the observation window to ages $25-60 .{ }^{4}$ In the SHP, we exclude all individuals who obtain, in later waves, a tertiary degree, leading to the omission of 150 individuals with general education and 273 with vocational education from our analytical sample.

Note that for a majority of labour force participants in Switzerland, the highest education is at the upper-secondary level. For our birth cohort 1954-1966, this is the case for 55 per cent-46 per cent with

\footnotetext{
${ }^{3}$ We do not use the SLFS's rotating panel, but only include, for each respondent, the first observation.

${ }^{4}$ Individuals continue to obtain tertiary education after their early twenties. However, Tables W.2 and W.3 in the web-appendix show that this applies to a similar extent to holders of upper-secondary vocational as to holder of uppersecondary general education after the age of 25 . Selectivity into tertiary education seems therefore to be comparable for the two groups over ages 25-60.
}

upper-secondary vocational education and 9 per cent with upper-secondary general education. Individuals with tertiary education account for 28 per cent and 16 per cent have not completed any upper-secondary education. Table Web A.1 in the web-appendix provides descriptive statistics.

When applying these restrictions, we obtain 55,391 observations for the 1954-1966 cohort of people aged between 25 and 60 with no more and no less than upper-secondary education. This provides us with an average of 701 observations for men and 837 for women per year of age. In the Swiss Household Panel, our analytical sample is smaller with 5566 individuals observed over an average of 6.2 years, which means a total of 34,640 observations. Per year of age, this corresponds to an average of 375 observations for men and 587 observations for women.

\subsection{Variables}

Our analysis focuses on individuals' labour market outcome measured with two dependent variables: employment and work income. Employment is coded as 1 if respondents are working for a minimum of $8 \mathrm{~h}$ per week and 0 if working less than $8 \mathrm{~h}$ per week or not at all. We replicate our results with an alternative specification of $20 \mathrm{~h}$ per week. Earnings are measured with gross hourly work income in constant 2011 Swiss francs (CHF), which we calculate by dividing monthly work income by the number of hours worked. ${ }^{5}$ We include the self-employed, but exclude respondents who are in marginal employment (working less than $8 \mathrm{~h}$ per week). While we impute earnings where missing, ${ }^{6}$ we remove wages lower than $12 \mathrm{CHF}$ and higher than $300 \mathrm{CHF}$ per hour.

Our key independent variables are education and age. In most analyses, we simply distinguish two types of education. Upper-secondary vocational education includes dual and school-based VET obtained in curricula of three to four years (including the minority of apprentices obtaining a vocational baccalaureate). Upper-secondary general education includes baccalaureate schools and, more marginally, other general schools with usually at least three years of post-mandatory schooling. For the descriptive analysis, we also show results for individuals with no upper secondary education (compulsory education or short upper-secondary level programs of no more than two years) and for individuals with tertiary education (university, university of applied science and tertiary vocational degrees).

We check for the varying quality of vocational degrees by distinguishing six types of VET based on the occupation for which respondents were initially trained: (1) agricultural and construction occupations; (2) technical and industrial production occupations; (3) technical office and computer science occupations; (4) commercial and clerical occupations; (5) occupations in private consumer services; (6) occupations in health and social services.

Measures for respondent's social origin are only available in the SHP. We use five categories to distinguish fathers' education, mothers' education, fathers' social class and mothers' social class. ${ }^{7}$ Additionally,

\footnotetext{
${ }^{5}$ The number of hours is based on the exact full-/part-time status given by the respondents and, where this information is missing, on the actual number of hours worked per week.

${ }^{6}$ In the SLFS, we impute missing earnings data using multiple imputations (package "mice" in $\mathrm{R}$, using five imputations) based on a regression model including age, age $e^{2}$ age $e^{3}$, age $e^{4}$, type of education, 26 cantons, type of municipality, residential permit as well as nationality. More complex models that additionally include sector, ISCO and job responsibility lead to the same results. Likewise, when comparing the results based on imputed earnings with results obtained with listwise deletion of missing data, we find very similar outcomes (results are available from the authors).

${ }^{7}$ For education, we use: (1) no more than compulsory education; (2) uppersecondary vocational education; (3) upper-secondary general education; (4) tertiary education, (5) missing. For social class, we use: (1) low-skilled working class including machine operators and elementary occupations in production, sales and services; (2) skilled working class including craft workers, clerks and
} 
we control for resident permit and, in the SLFS, for nationality (in 20 categories), for Switzerland's 26 cantons and for nine types of residential community (from small village to large urban centre).

\subsection{Selection}

The allocation of young people into different educational tracks is not random, but riddled with selection effects. We do not have a silver bullet to deal with selection, but use a multi-pronged strategy to reduce its impact.

We focus on a given cohort and thus do not compare the labour market outcomes of individuals who were educated and entered the labour market in different historical periods. We further narrow down our analytical sample to individuals whose highest educational attainment is at the upper-secondary level and who thus typically spent 12-13 years in full-time education. Thereby, we exclude both the least motivated students who did not obtain a degree at the upper-secondary level and the most able students who went on to either post-secondary vocational or university education. ${ }^{8}$

More generally, male students from a lower class origin, the German-speaking and rural cantons are more likely to go to the vocational track, whereas female students from a higher class origin, the French-speaking cantons and cities are more prone to choose the general track (Wolter et al., 2014: 107). We thus control for canton, type of municipality, nationality (which, in our birth cohort, correlates with class origin) and, in the SHP, for both parents' education and social class. Moreover, we run all our analysis separately for men and women. $^{9}$

While we are confident that these measures - and notably the comparison between holders of upper-secondary vocational and general education in a given cohort - go some way to reducing selection, we do not have an explicit causal design, but present population associations.

\subsection{Estimation method}

We test the arguments about the evolution of employment and earnings over the life course in a simple regression setup. The equation of our linear regression is given as:

$$
\begin{aligned}
y_{i}= & \beta_{1}+\beta_{2} \text { educ }_{i}+\beta_{3} \text { age }_{i}+\beta_{4} \text { age }_{i}^{2}+\beta_{5} \text { age }_{i}^{3}+\beta_{6} \text { age }_{i}^{4} \\
& +\beta_{7} \text { educ }_{i} * \operatorname{age}_{i}+\beta_{8} \text { educ }_{i} * \operatorname{age}_{i}^{2} \\
=+ & \beta_{9} \text { educ }_{i} * \operatorname{age}_{i}^{3}+\beta_{10} \text { educ }_{i} * \operatorname{age}_{i}^{4}+\beta_{11} W_{i}+\varepsilon_{i}
\end{aligned}
$$

Our dependent variable $y_{i}$ is, in a first equation, a binary measure of employment $(0 / 1)$ and in a second equation the logarithm of hourly wages for an individual $i$ at time $t$. $W_{i}$ is a vector of controls and $\varepsilon_{i}$ is the

\section{(footnote continued)}

skilled sales and service workers; (3) lower-middle class of associate managers, semi-professionals and technicians; (4) upper-middle class of managers and professionals; (5) Missing. Occupations were coded on the basis of the International Standard Classification of Occupations (ISCO) 1988 at the 4-digit levels. The Stata codes are available from the authors.

${ }^{8}$ Among individuals with upper-secondary general education, a sizeable proportion may obtain a few years of university education without graduating (and would therefore fall in the United States into the category of having "some college"). We thus possibly underestimate their effective years of education by measuring it with the highest degree that they acquired.

${ }^{9}$ We tested - and discarded - two instrumental variables widely used in the literature: institutional school differences and mothers' education (Card, 1999: 1822). We used the baccalaureate rate in a given canton in a given year for girls and boys. This rate is set by each canton independently and varies over time and across cantons: if it is low, average students are less likely to go to a baccalaureate school and more likely to choose VET. Unfortunately, the baccalaureate rate turned out to be a weak instrument that leads to biased estimates. Likewise, the correlation between mothers' education and children's education is low and the instrument weak. error term. Our two main predictors are a dichotomous measure for the type of upper-secondary education, $e d u c_{i}$, which measures the initial labour market prospects of vocational relative to general education, and the interaction between education and age $e d u c_{i} * a g e_{i}$ which accounts for a differential age-evolution of the two educational groups. ${ }^{10}$

As the descriptive results will show, employment and earnings do not follow a linear trend, but evolve in a polynomial pattern over the life-course. Therefore, we estimate a model with age squared, cubed and to the power of four $\left(a g e_{i}^{2}, a g e_{i}^{3}, a g e_{i}^{4}\right.$ ) with the respective interactions terms between education and age: $e d u c_{i} * a g e_{i}^{2}, e d u c_{i} * a g e_{i}^{3}$ and $e d u c_{i} * a g e_{i}^{4}$. We help readers to interpret our results by graphically plotting them. Note that we use individual cross-sectional survey weights for the descriptive results, but not for the regression models in order to avoid accounting twice for the same socio-demographic control variables.

\section{Empirical results}

\subsection{Employment over the life course}

We begin our analysis by describing the evolution of employment for the cohort born between 1954 and 1966. Fig. 1 shows how the employment rate varies by age for men and women with different types and levels of education. Over most of the life course, individuals with tertiary education have the highest and individuals without post-mandatory schooling the lowest employment rate among both men and women.

If we focus on the bulk of the cohort who has upper-secondary education, we find men with VET to have a substantial employment advantage over men with general education up to the age of around 40. While the difference becomes smaller thereafter, vocationally trained men are not overtaken, in terms of the employment rate, by men with upper-secondary general education in the second half of their careers.

For women, we do not observe an employment advantage of VET over general education at the start of the careers. On the contrary, up to the age of 35 , vocationally trained women have lower employment rates than women with general education. After that age, they catch up and the two groups with vocational and general upper secondary education evolve in parallel until their retirement.

If we choose a more restrictive definition of employment - at least $20 \mathrm{~h}$ of work per week - we observe a similar pattern for men, but the employment advantage of the vocationally trained becomes larger. For women, the exclusion of small part-timers leads to a drop in the employment rate of 10 percentage points and the early employment advantage of general education over VET becomes smaller (see Figure Web A.1 in the web-appendix).

We move on to estimate a multivariate linear probability model on the employment prospects for men and women with upper-secondary vocational and general education. Since age is entered as a polynomial term with several interactions, we make sense of the results by plotting in Fig. 2 the difference between vocational and general education (that is, we show the average marginal effects). Both datasets suggest that there is a large initial employment advantage of vocationally trained men over men with general education. While this advantage becomes smaller over time and virtually disappears in the early thirties, it never turns into a disadvantage. Holders of vocational qualifications therefore do not have a harder time securing employment over the second half of their career than individuals with general education. If anything, their employment prospects seem slightly better. For women, the differences

\footnotetext{
${ }^{10}$ Hanushek et al. (2017: 57-58) argue, somewhat optimistically, that this model emulates a difference-in-differences approach where the coefficient of $e d u c_{i}$ includes any selectivity into types of education that are not captured by $W_{i}$, whereas the interaction $e d u c_{i} * a g e_{i}$ identifies the causal effect of different types of education over the life course.
} 

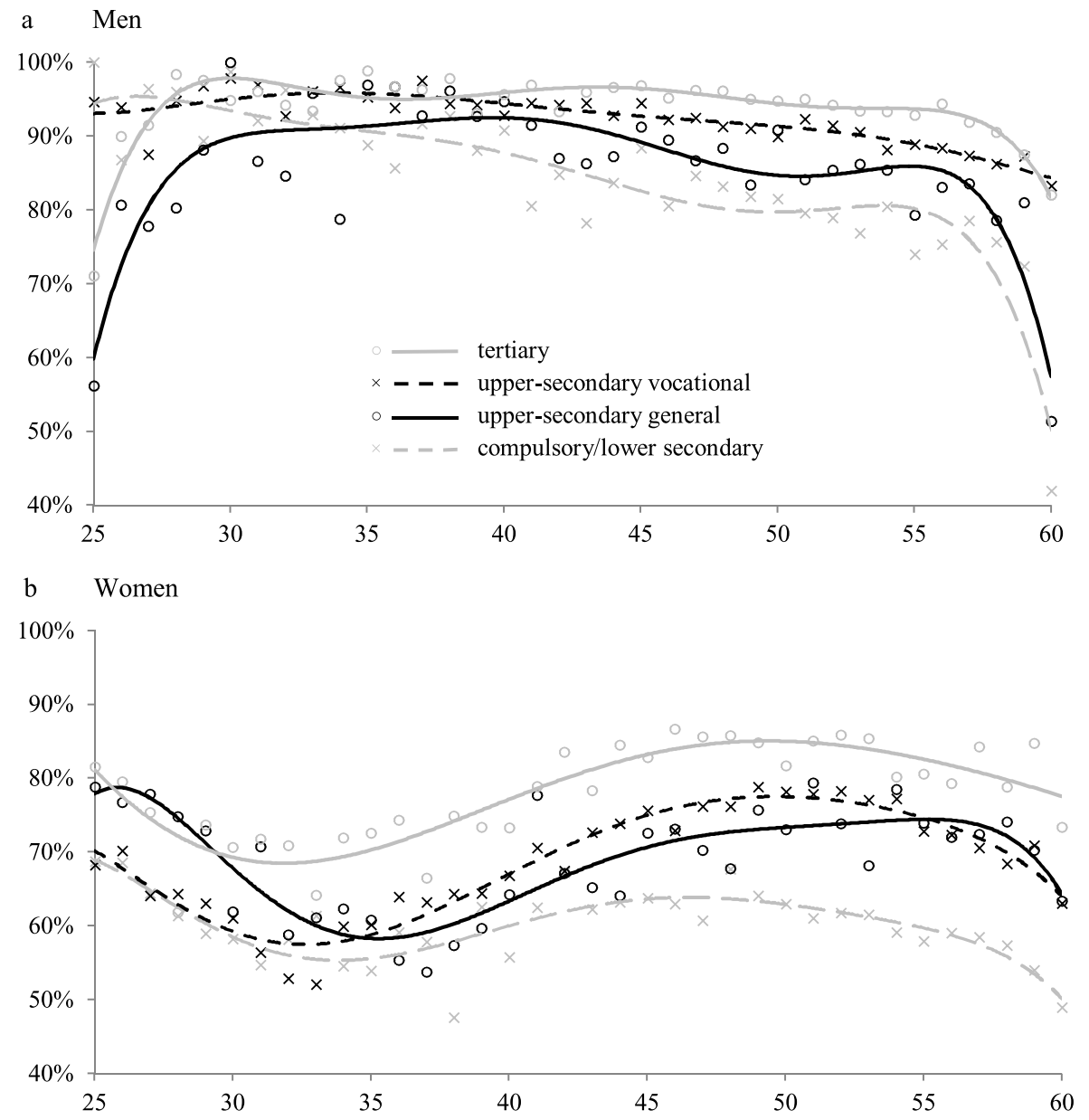

Fig. 1. Employment rate for types of education by age.

Data: SLFS 1991-2014 (for cohort born 1954-66).

Note: Employment of a minimum of $8 \mathrm{~h}$ per week. Dots represent the mean employment rate at each age for the four educational groups. Lines show the polynomial trend lines.

are smaller and suggest that the employment rates of the two educational groups do not vary in a systematic matter. While women with general education may have somewhat higher employment rates in their early thirties than vocationally trained women, the key finding is that the employment prospects of women with either vocational or general education are very similar over the life course.

Do these results also hold if we examine unemployment instead of employment, and thus exclude people from our analysis who are inactive for other reasons (notably linked to family or health)? We introduce all our control variable into a linear probability model on unemployment and plot the difference in predictive margins between holders of vocational and general education. ${ }^{11}$ The result shows that the two educational groups do not vary in their unemployment risks over the life course (see Fig. A.1 in the appendix). The difference oscillates between +3 and -2 percentage points and does not reach statistical significance for any year of age for either men or women. In Switzerland's context of low unemployment, labour market prospects seem to be better captured by employment rates than unemployment rates.

\footnotetext{
${ }^{11}$ Following Moffitt (1999), we show the results from linear probability models. Note, however, that we replicated all our analyses with binomial logistic regression models. The results show the same age-employment and ageunemployment curves and lead to identical conclusions (results available from the authors).
}

We return to the outcome variable of employment and estimate the same model as in Fig. 2 for an older (1941-53) and younger birth cohort (1967-79). The results do not change with respect to those found for our target cohort 1954-66. For the older birth cohort - which we observe over the ages 40-60-, we detect no differences in employment rates between holders of vocational and general education. For the younger cohort - which we observe over the ages 25-45-, we find a higher employment rate of holders of vocational education until the age of 26 for women and until the age of 33 for men (see Fig. A.2 in the appendix). In terms of employability, vocational education seems to have remained as instrumental for younger as older cohorts.

\subsection{Earnings over the life course}

We shift our focus to earnings and show in Fig. 3 how hourly work income varies by age for different levels and types of education. Contrary to our findings for employment, general education offers a clear advantage in terms of earnings. Already at the age of 30, men and women with no more than upper-secondary general education receive higher hourly work income than those with upper-secondary vocational training. However, both educational groups remain well beneath the earnings of workers with tertiary education. After the age of 30 , the earnings of workers with upper-secondary general education continue to increase, whereas the earnings curve of vocationally trained workers is almost as flat as that of individuals without post-compulsory 
a Men - SLFS, cohort 1954-66

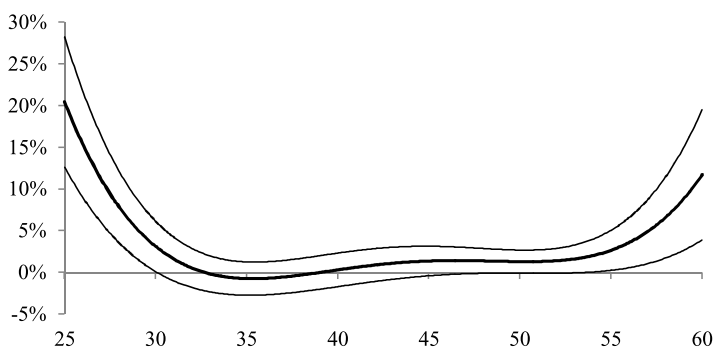

c Men-SHP, cohort 1950-79

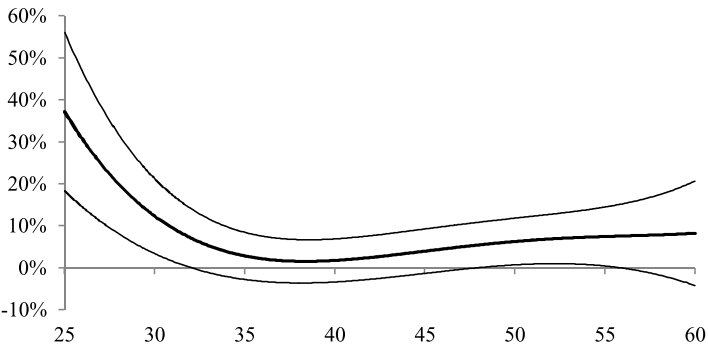

b Women - SLFS, cohort 1954-66

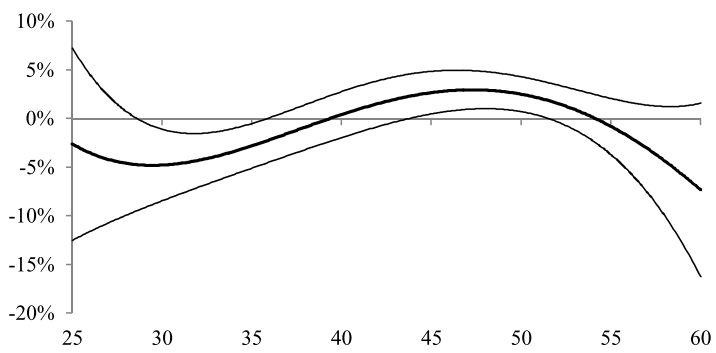

d Women - SHP, cohort 1950-79

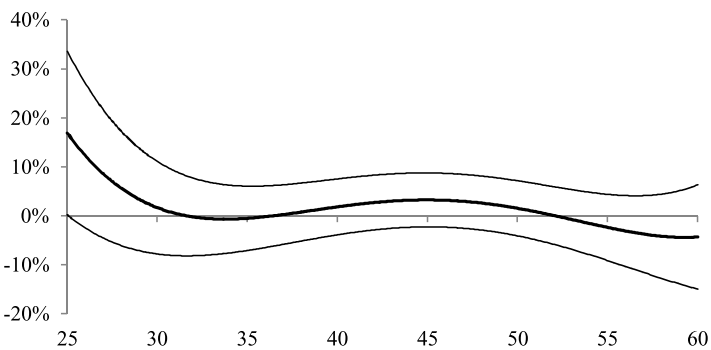

Fig. 2. Difference in employment by age for upper-secondary vocational relative to general education (average marginal effects).

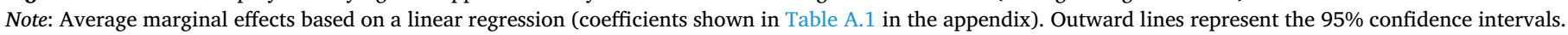

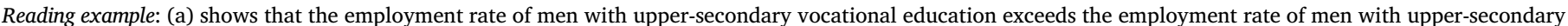
general education by 20 percentage points at age 25 .

Data: SLFS 1991-2014, SHP 1999-2015.
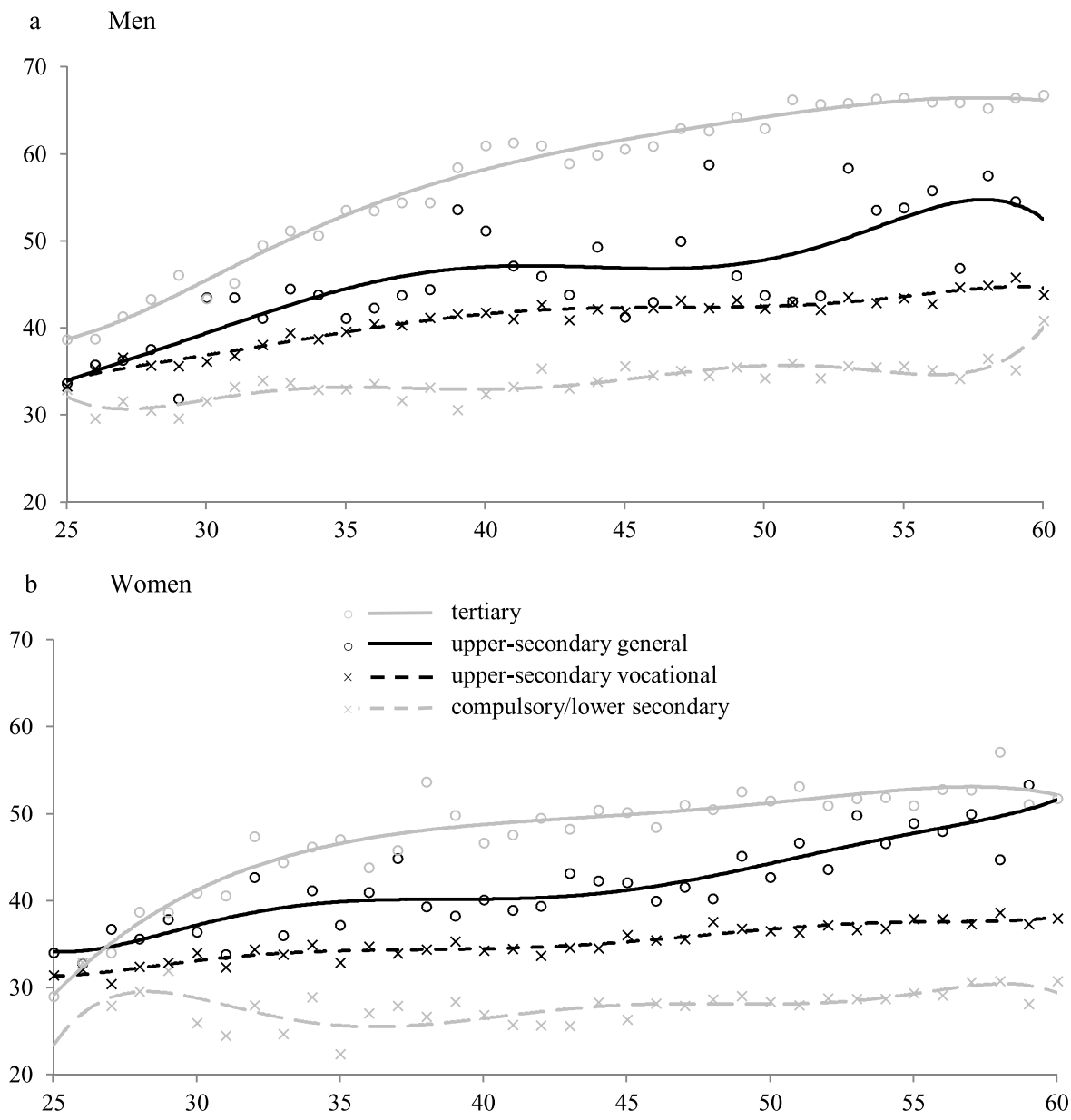

Fig. 3. Median hourly work income for types of education by age (in 2011 Swiss francs).

Data: SLFS 1991-2014 (for cohort born 1954-66).

Note: Dots represent the mean earnings at each age for the four educational groups. Lines show the polynomial trend lines. 


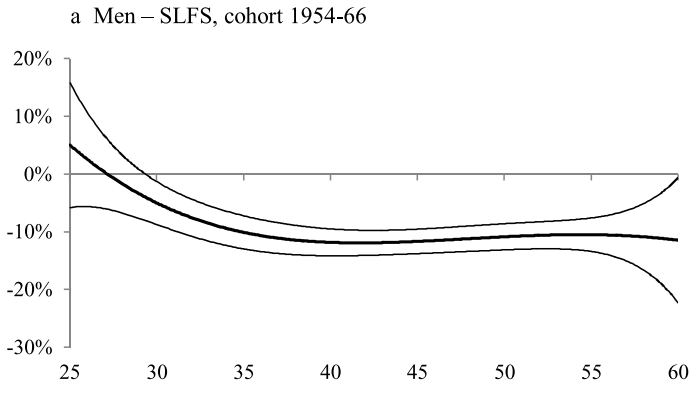

c Men-SHP, cohort 1950-79

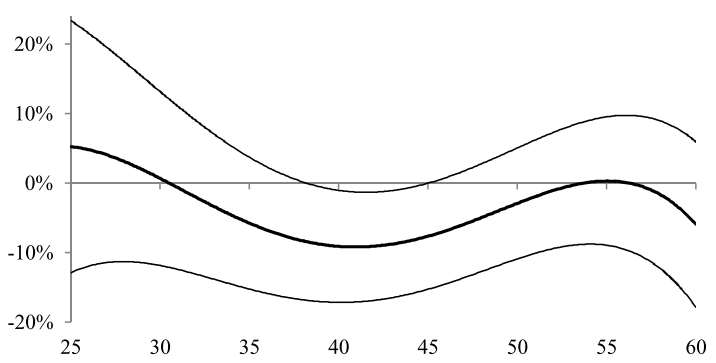

b Women - SLFS, cohort 1954-66

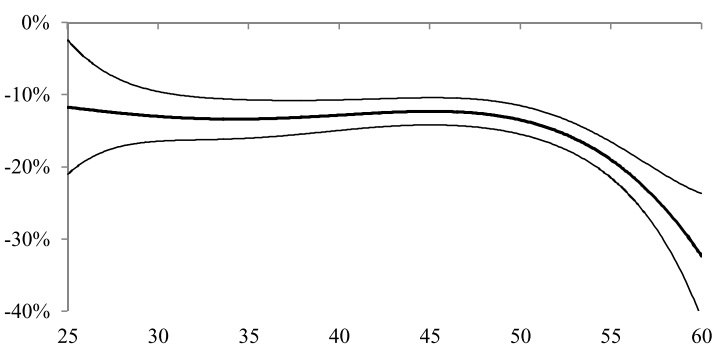

d Women - SHP, cohort 1950-79

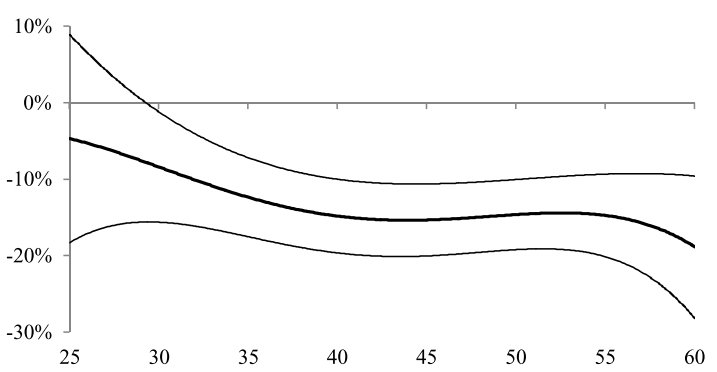

Fig. 4. Difference in hourly wages (in \%) by age for upper-secondary vocational relative to general education (average marginal effects).

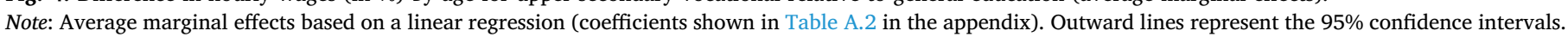

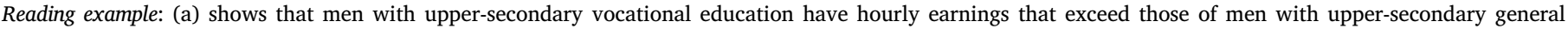
education by 5 per cent at age 25, while they are 10 per cent lower at age 40. Data: SLFS 1991-2014, SHP 1999-2015.

schooling. As a result, the gap in hourly earnings widens over the life course in favour of workers with general education.

Our multivariate models confirm these findings. In Fig. 4, we plot again the difference of work income over ages 25-60 between holders of upper-secondary vocational education and holders of upper-secondary general education (see Table A.2 in the appendix for the coefficients). For men, hourly work income is comparable for the two educational groups at the age of 25 , with a slight but non-significant advantage for holders of VET. Yet, thereafter, earnings increase more for general than vocational education until the growth curve levels off and the difference stabilises when workers reach their forties.

For women, general education is associated with higher hourly wages already at the age of 25 in comparison to vocational education. The SLFS suggests that at the age of 40, workers with general education earn 12 (men) to 13 per cent (women) more per hour than their vocationally trained colleagues. While the analysis for the SHP is based on a smaller sample and repeated observations, thus producing larger confidence intervals, it leads to the same basic finding that the life-cycle earnings-curve is significantly steeper for general than vocational education.

If we estimate the same model for an older (1941-53) and younger birth cohort (1967-79), we obtain similar findings as for our target cohort 1954-1966. In the older birth cohort (observed over the ages 40-60), hourly wages are systematically higher for both men and women having general rather than vocational education. In the younger cohort 1967-79 (observed over the ages 25-45), among men the two educational groups have a similar hourly wage at the age 25 , but the earnings curve is again steeper for the holders of general education (see Fig. A.3 in the appendix). Among women, general education comes with an earnings advantage already at the age of 25 .

\subsection{Robustness tests}

Up to now, we have treated VET as a homogeneous type of education. However, the labour market value of a vocational degree may depend on the occupation in which it was obtained. We therefore calculate hourly earnings for each of the six fields of vocational training discussed above (see Figure Web A.2 in the web-appendix). While there are substantial differences in earnings across vocational fields, the conclusions remain unchanged: General education is associated with higher hourly earnings than every single one of the six fields of VET that we distinguish. The first runner-up are vocational degrees in technical and industrial production occupations followed by vocational degrees in commercial and clerical occupations. By contrast, the lowest hourly earnings are paid for vocational degrees in private consumer services that include occupations such as vendors, waiters or hairdressers.

Finally, the question arises as to whether individuals with vocational training succeed in working longer hours and thereby compensate for their lower hourly earnings. We address this question by calculating the annual earnings of people working at least $8 \mathrm{~h}$ per week (see Figures Web A.3 and A.4 in the web-appendix). ${ }^{12}$ Overall, the earnings gaps between workers in the two educational groups are similar when we use annual instead of hourly work income. However, at the beginning of careers, annual work incomes show a clearer advantage of VET for men and a smaller advantage of general education for women. Men with vocational degrees obtain higher annual earnings than their colleagues with general education up to the age of 27, whereas vocationally trained women have a similar annual work income than women with general education until the age of 28 . Thereafter, we observe again a reversal of fortunes as annual earnings increase more for holders of general than vocational education.

\section{Discussion and conclusion}

Our paper has examined three arguments about the long-term

\footnotetext{
${ }^{12}$ SLFS provides information on the effective annual work income, regardless of working hours. For this analysis, we discarded the work income of people who are not in the labour market or employed in marginal jobs (working less than 8 hours per week), left away outliers (the top and bottom percent of the distribution) and imputed missing values (see footnote 6 ).
} 
prospects of vocationally trained workers. A first argument expects them to keep and extend their initial labour market advantage over the life course. A second argument presumes that vocational skills become more quickly obsolete than skills obtained in general education, leading vocationally trained workers to fall behind those with general education. A third argument expects very similar labour market outcomes by types of education once heterogeneity of vocational degrees and selection into tracks are accounted for.

Our analysis does not designate a clear winner among these three arguments. With respect to employment, our findings support the first thesis. In Switzerland, vocational training is associated with a substantial employment advantage at the beginning of the career for men, but less so for women. Contrary to the idea that vocationally trained workers are outpaced by structural change, we find that their employment rates remain high over the entire career and do not fall beneath those of workers with general education - contrary to what Hanushek et al. (2017) find for their small cross-sectional samples. Moreover, our analysis shows no systematic differences across birth cohorts and suggests that the labour market prospect of vocational relative to general education has not deteriorated over time. While these finding may be specific to Switzerland and its context of low unemployment, Forster et al. (2016) show that the age-employment curves of vocationally trained workers vary little across OECD countries.

Results are different for earnings, where our findings support the second argument. Men, but not women, with upper-secondary general education struggle with a slower start in the labour market. However, once they launch their career, their wage curves are steeper than for vocationally trained workers. As a result, there is a reversal of fortunes between the two educational groups as both men and women with general education earn higher work income from their thirties onwards, regardless whether one looks at hourly or annual earnings.

A final result worth noting relates to gender differences: the nexus between education and labour market outcomes looks different for men than women. It is standard practice in labour economics to limit analyses to men and then extrapolate these results to the entire population (e.g. Hanushek et al., 2017: 52; Malamud \& Pop-Eleches, 2010: 44). This is misleading with respect to the labour market outcomes associated with vocational education. While vocationally trained men have a significant employment advantage in early careers over men with general education, this is not the case for vocationally trained women. This result is consistent with the finding by Forster et al. (2016) that the early-career advantage of vocational education reverses faster into a disadvantage for women than men.

Why would vocational education be more instrumental for men than women? Vocational education was originally devised to train craftsmen and is thus still more relevant to, and possibly more rewarding in, traditionally male- than female-dominated occupations (Murphy \& Oesch, 2016). In addition, skills learnt in firm-based vocational training are more specific and thus less well portable from one firm to another. This smaller portability of specific skills may make vocational education less attractive to women who plan to interrupt their career in order to raise a family. Likewise, if employers anticipate that more women than men quit their job for family reasons, they will be less inclined to invest into the job-specific skills of their female employees (Estévez-Abe, 2005: 190).

The finding that vocational education provides better employment prospects to men - and general education to women - echoes the evolution of Switzerland's baccalaureate rate over the last 25 years. In 1990, women equalled men's baccalaureate rate for the first time (at 13.5 per cent). Since then, women's baccalaureate rate continuously climbed (to 24.5 per cent in 2015), whereas men's rate has more or less stagnated at 17 per cent. It looks as if youth and their parents examine labour market signals closely before making educational choices.

In policy terms, these findings caution against the overly enthusiastic endorsement of vocational education. While vocational degrees facilitate the transition from school to work and hence protect against youth unemployment, they also seem to limit workers' longterm productivity and thus come at the cost of flat earning curves over the life course. In other words, vocational training reduces the risk of unemployment and downwards social mobility, but may also limit the likelihood of entry into the upper-middle class and upwards social mobility (Breen \& Goldthorpe, 1997: 283).

These findings point to the crucial importance of further education for career advancement. While continued adult education is skewed - in Switzerland as elsewhere in the OECD - towards individuals with university degrees, Switzerland's professional education and training (PET) system offers many progression opportunities for graduates of upper secondary vocational education. No less than 20 per cent of Switzerland's labour force held a PET degree in 2009 and had thus joined - at the mean age of 30 - the growing ranks of workers with a tertiary education (OECD, 2013: 13). An initial degree at the tertiary level - be it a bachelor or a PET degree - may thus increasingly become the standard entry-level education on the labour market as individuals with tertiary degrees become the largest educational group, in Switzerland as elsewhere in Western Europe (Babel, 2019).

Finally, we wish to caution against the over-generalization of our findings. They refer to a specific cohort, country and historical period and coincide with the transition from an industrial to a service-based economy in the context of low unemployment. With on-going digitalization, globalization and educational expansion, young adults who obtain an upper-secondary vocational degree today may well face different employment prospects in the second half of their careers than did the Swiss cohort that left the educational system in the 1970s and 1980s.

\section{Acknowledgements}

This paper was written within the Swiss National Centre of Competence in Research "LIVES - Overcoming vulnerability: life course perspectives", funded by the Swiss National Science Foundation. We gratefully acknowledge the comments made by seminar participants in Bamberg (SLLS), Bern (RC28), Oxford (ECSR), Paris (CREST), Tallinn (ECSR), Villars (Alp-Pop) as well as the helpful inputs received from André Berchtold, Bastian Betthäuser, Thijs Bol, Julie Falcon, Ben Jann, Irene Kriesi, Rafael Lalive, Oliver Lipps, Patrick McDonald, Leen Vandecasteele as well as the editor Laura Bernardi and two anonymous reviewers. 


\section{Appendix A}
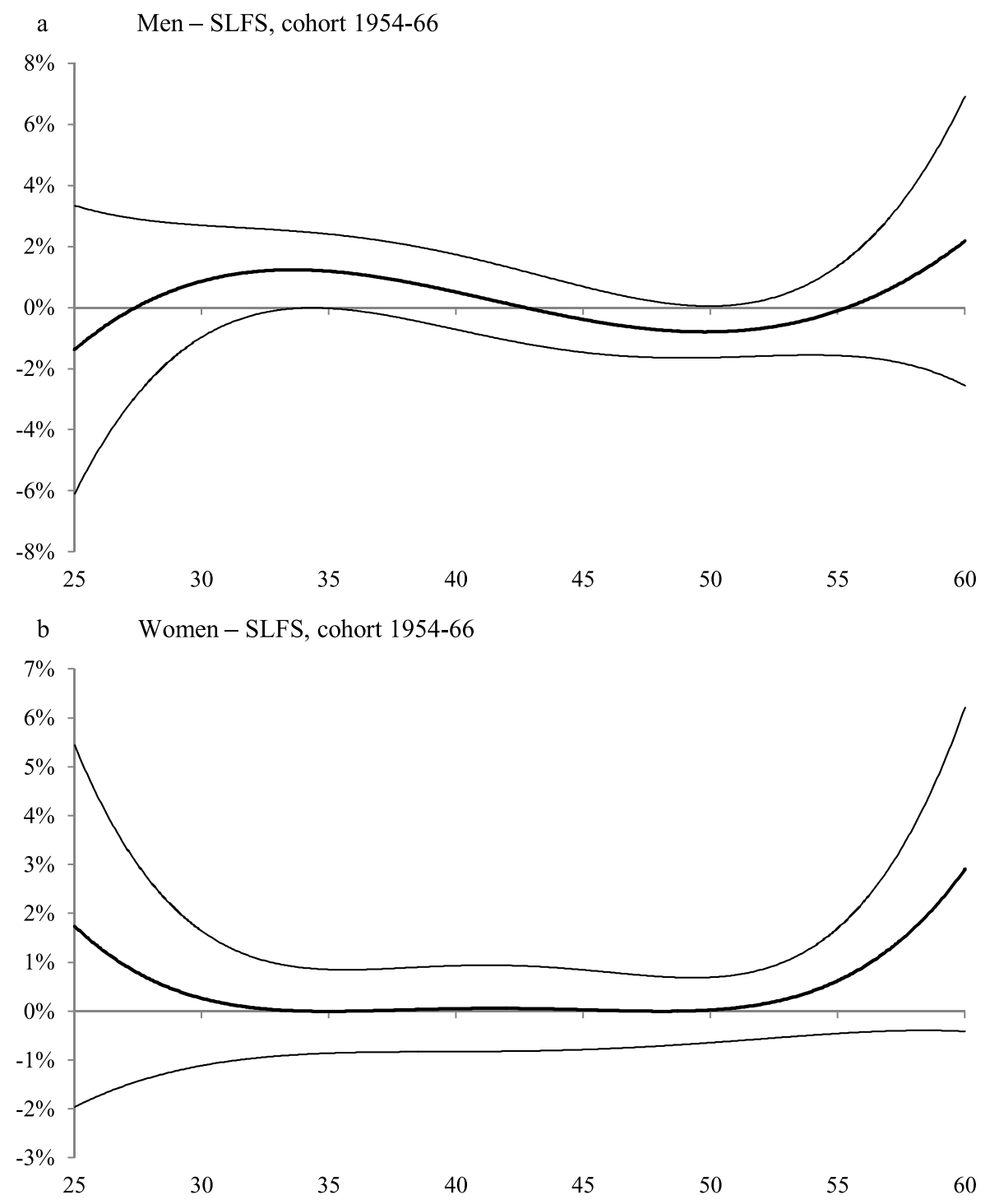

Fig. A.1. Difference in unemployment rates by age for upper-secondary vocational relative to general education (average marginal effects). Note: Average marginal effects based on a linear regression (see legend of Table A.1 in the appendix for information on the control variables). Data: SLFS 1991-2014. 

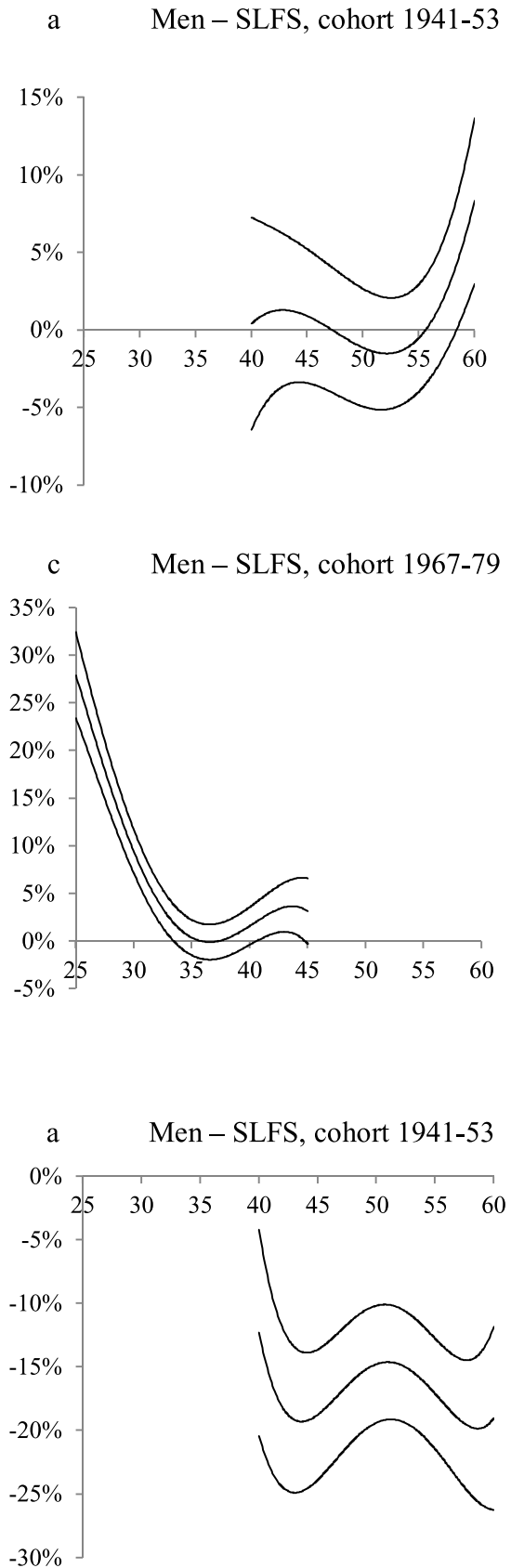

c $\quad$ Men - SLFS, cohort 1967-79

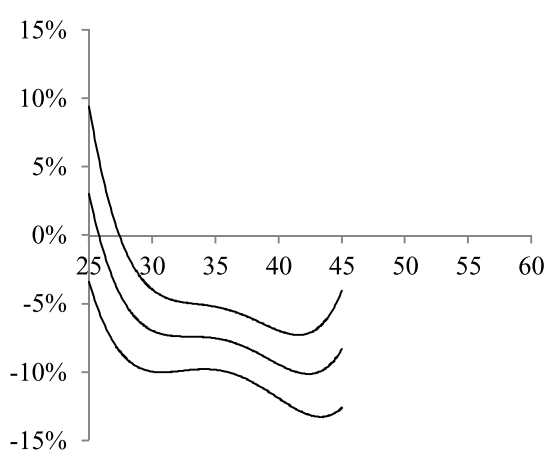

b Women - SLFS, cohort 1941-53

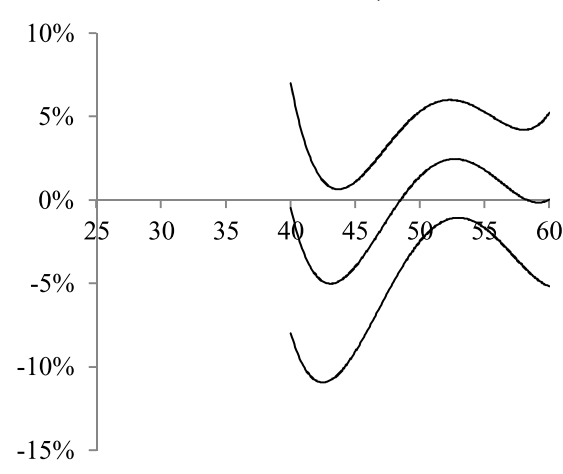

d Women - SLFS, cohort 1967-79

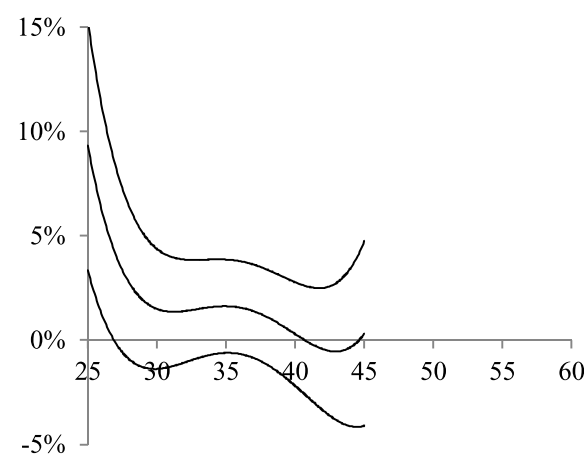

b Women - SLFS, cohort 1941-53

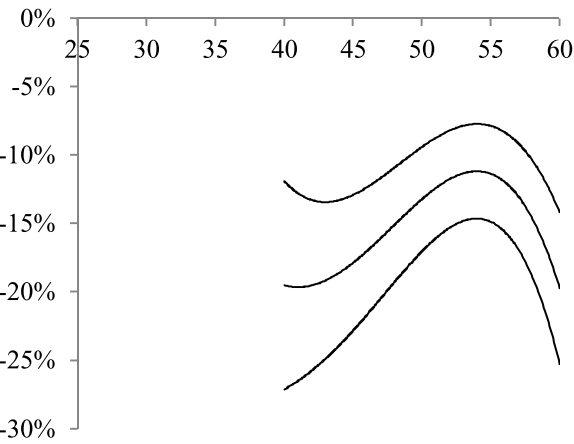

d Women - SLFS, cohort 1967-79

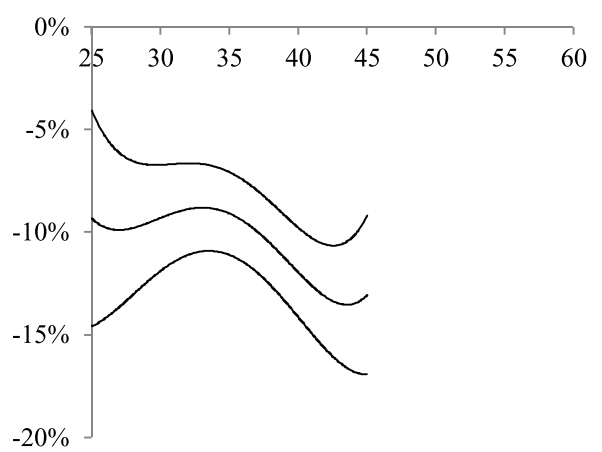

Fig. A.2. Difference in employment by age for uppersecondary vocational relative to general education (average marginal effects) for two birth cohorts. Data: SLFS 1991-2014.

Note: Average marginal effects based on a linear regression on employment (see Table A.1 for control variables). Outward lines represent the $95 \%$ confidence intervals.
Fig. A.3. Difference in hourly wages (in \%) by age for upper-secondary vocational relative to general education (average marginal effects) for two birth cohorts. Data: SLFS 1991-2014.

Note: Average marginal effects based on a linear regression on hourly wages (see Table A.2 for control variables). Outward lines represent the $95 \%$ confidence intervals. 
Table A.1

Linear regression coefficients for being in employment (min $8 \mathrm{~h}$ per week).

\begin{tabular}{|c|c|c|c|c|c|c|c|c|c|}
\hline & & \multicolumn{4}{|l|}{ Men } & \multicolumn{4}{|l|}{ Women } \\
\hline & & \multicolumn{2}{|c|}{ Without controls } & \multicolumn{2}{|c|}{ With controls } & \multicolumn{2}{|c|}{ Without controls } & \multicolumn{2}{|c|}{ With controls } \\
\hline & & coeff & SE & coeff & SE & coeff & SE & coeff & SE \\
\hline \multirow[t]{12}{*}{ SLFS, cohort 1954-66 } & age & 11.1 & 2.51 & 8.47 & 2.48 & -3.88 & 2.83 & -5.36 & 2.82 \\
\hline & age $^{2}$ & -3.89 & 0.92 & -2.92 & 0.91 & 1.17 & 1.03 & 1.75 & 1.03 \\
\hline & $\operatorname{age}^{3}$ & 0.59 & 0.15 & 0.44 & 0.15 & -0.15 & 0.17 & -0.24 & 0.16 \\
\hline & age $^{4}$ & -0.03 & 0.01 & -0.03 & 0.01 & 0.01 & 0.01 & 0.01 & 0.01 \\
\hline & educ: voc & 9.95 & 2.69 & 8.70 & 2.66 & 2.92 & 3.22 & 2.22 & 3.20 \\
\hline & age*educ: voc & -9.43 & 2.69 & -8.19 & 2.65 & -2.96 & 3.19 & -2.17 & 3.18 \\
\hline & age $^{2 *}$ educ: voc & 3.30 & 0.98 & 2.86 & 0.97 & 1.03 & 1.17 & 0.73 & 1.16 \\
\hline & age $^{3 *}$ educ: voc & -0.51 & 0.16 & -0.44 & 0.15 & -0.15 & 0.19 & -0.10 & 0.19 \\
\hline & age $^{4 *}$ educ: voc & 0.03 & 0.01 & 0.03 & 0.01 & 0.01 & 0.01 & 0.01 & 0.01 \\
\hline & constant & -10.8 & 2.51 & -8.14 & 2.48 & 5.26 & 2.84 & 6.614 & 2.83 \\
\hline & Adjusted $R^{2}$ & \multicolumn{2}{|c|}{0.013} & \multicolumn{2}{|c|}{0.043} & \multicolumn{2}{|c|}{0.016} & \multicolumn{2}{|c|}{0.029} \\
\hline & $N$ & \multicolumn{2}{|c|}{25,168} & \multicolumn{2}{|c|}{25,168} & \multicolumn{2}{|c|}{29,667} & \multicolumn{2}{|c|}{29,667} \\
\hline \multirow[t]{12}{*}{ SHP. cohort 1950-79 } & age & 11.7 & 4.51 & 11.7 & 4.48 & 0.54 & 4.769 & 0.45 & 4.69 \\
\hline & age $^{2}$ & -3.89 & 1.64 & -3.88 & 1.63 & -0.45 & 1.716 & -0.42 & 1.68 \\
\hline & $\operatorname{age}^{3}$ & 0.57 & 0.26 & 0.57 & 0.26 & 0.12 & 0.268 & 0.11 & 0.26 \\
\hline & $\operatorname{age}^{4}$ & -0.03 & 0.02 & -0.03 & 0.02 & -0.01 & 0.015 & -0.01 & 0.02 \\
\hline & educ: voc & 7.54 & 4.72 & 7.76 & 4.68 & 8.44 & 5.315 & 8.14 & 5.25 \\
\hline & age*educ: voc & -6.22 & 4.66 & -6.44 & 4.63 & -8.00 & 5.231 & -7.64 & 5.15 \\
\hline & age $^{2 *}$ educ: voc & 1.90 & 1.69 & 1.97 & 1.68 & 2.77 & 1.880 & 2.63 & 1.85 \\
\hline & age $^{3 *}$ educ: voc & -0.25 & 0.27 & -0.26 & 0.27 & -0.41 & 0.293 & -0.39 & 0.29 \\
\hline & age $^{4 *}$ educ: voc & 0.01 & 0.02 & 0.01 & 0.02 & 0.02 & 0.017 & 0.02 & 0.02 \\
\hline & constant & -12.1 & 4.56 & -12.1 & 4.54 & 0.65 & 4.833 & 0.45 & 4.69 \\
\hline & Adjusted $R^{2}$ & \multicolumn{2}{|c|}{0.055} & \multicolumn{2}{|c|}{0.074} & \multicolumn{2}{|c|}{0.011} & \multicolumn{2}{|c|}{0.029} \\
\hline & $N$ & \multicolumn{2}{|c|}{13,378} & \multicolumn{2}{|c|}{13,378} & \multicolumn{2}{|c|}{20,494} & \multicolumn{2}{|c|}{20,494} \\
\hline
\end{tabular}

SLFS: Swiss Labor Force Survey 1991-2014, SHP: Swiss Household Panel 1999-2015.

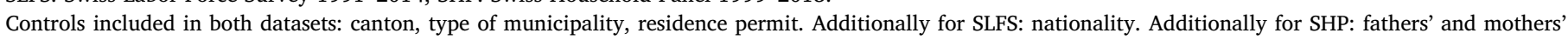
education, fathers' and mothers' social class.

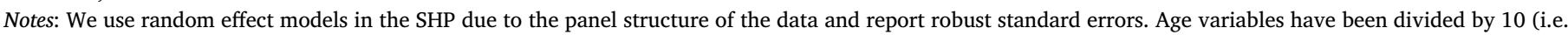
age 25 is expressed as 2.5 , age 45 as 4.5 ).

Bold: significant at $p<0.05$.

Table A. 2

Linear regression coefficients for (log) hourly work income.

\begin{tabular}{|c|c|c|c|c|c|c|c|c|c|}
\hline & & \multicolumn{4}{|l|}{ Men } & \multicolumn{4}{|l|}{ Women } \\
\hline & & \multicolumn{2}{|c|}{ Without controls } & \multicolumn{2}{|c|}{ With controls } & \multicolumn{2}{|c|}{ Without controls } & \multicolumn{2}{|c|}{ With controls } \\
\hline & & coeff & SE & coeff & SE & coeff & SE & coeff & SE \\
\hline \multirow[t]{12}{*}{ SLFS, cohort 1954-66 } & age & 4.22 & 3.55 & 0.63 & 3.41 & 1.41 & 2.76 & -1.73 & 2.71 \\
\hline & age $^{2}$ & -1.19 & 1.30 & 0.10 & 1.25 & -0.39 & 1.01 & 0.80 & 0.99 \\
\hline & $\operatorname{age}^{3}$ & 0.14 & 0.21 & -0.05 & 0.20 & 0.04 & 0.16 & -0.15 & 0.16 \\
\hline & age $^{4}$ & -0.01 & 0.01 & 0.00 & 0.01 & 0.00 & 0.01 & 0.01 & 0.01 \\
\hline & educ: voc & 4.12 & 3.79 & 2.11 & 3.63 & 1.73 & 3.13 & -0.50 & 3.07 \\
\hline & age*educ: voc & -3.60 & 3.77 & -1.65 & 3.62 & -1.66 & 3.12 & 0.62 & 3.06 \\
\hline & age $^{2 *}$ educ: voc & 1.12 & 1.38 & 0.44 & 1.32 & 0.51 & 1.14 & -0.34 & 1.12 \\
\hline & age $^{3 *}$ educ: voc & -0.15 & 0.22 & -0.05 & 0.21 & -0.06 & 0.18 & 0.07 & 0.18 \\
\hline & age $^{4 *}$ educ: voc & 0.01 & 0.01 & 0.00 & 0.01 & 0.00 & 0.01 & -0.01 & 0.01 \\
\hline & constant & -1.61 & 3.56 & 1.92 & 3.43 & 1.84 & 2.76 & 4.77 & 2.72 \\
\hline & Adjusted $R^{2}$ & \multicolumn{2}{|c|}{0.020} & \multicolumn{2}{|c|}{0.101} & \multicolumn{2}{|c|}{0.035} & \multicolumn{2}{|c|}{0.094} \\
\hline & $N$ & \multicolumn{2}{|c|}{22,665} & \multicolumn{2}{|c|}{22,665} & \multicolumn{2}{|c|}{20,806} & \multicolumn{2}{|c|}{20,806} \\
\hline \multirow[t]{7}{*}{ SHP. cohort 1950-79 } & age & -3.93 & 5.20 & -4.12 & 5.09 & 1.07 & 3.35 & 1.28 & 3.41 \\
\hline & $\operatorname{age}^{2}$ & 1.89 & 1.86 & 1.99 & 1.81 & -0.26 & 1.20 & -0.35 & 1.23 \\
\hline & age $^{3}$ & -0.35 & 0.29 & -0.37 & 0.28 & 0.03 & 0.19 & 0.05 & 0.19 \\
\hline & age $^{4}$ & 0.02 & 0.02 & 0.02 & 0.02 & -0.00 & 0.01 & -0.00 & 0.01 \\
\hline & educ: voc & -3.03 & 5.59 & -3.97 & 5.48 & -0.69 & 3.86 & -1.37 & 3.90 \\
\hline & age*educ: voc & 3.72 & 5.47 & 4.73 & 5.37 & 0.98 & 3.79 & 1.67 & 3.83 \\
\hline & age $^{2 *}$ educ: voc & -1.59 & 1.95 & -1.98 & 1.92 & -0.49 & 1.36 & -0.73 & 1.38 \\
\hline
\end{tabular}




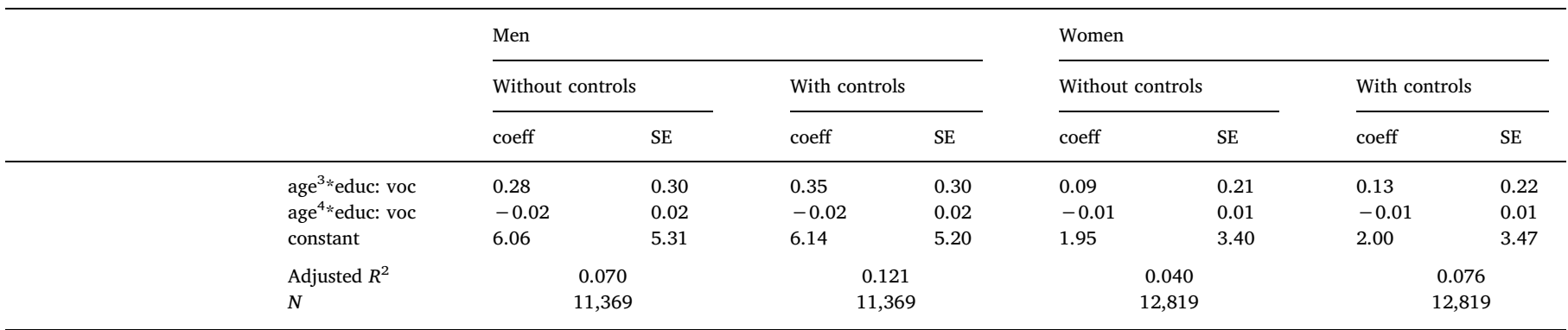

SLFS: Swiss Labor Force Survey 1991-2014, SHP: Swiss Household Panel 1999-2015.

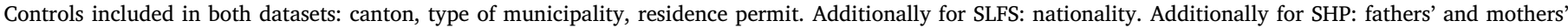
education, fathers' and mothers' social class.

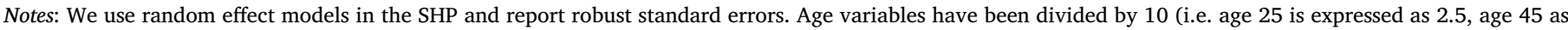
4.5).

Bold: significant at $p<0.05$.

\section{Appendix B. Supplementary data}

Supplementary data associated with this article can be found, in the online version, at https://doi.org/10.1016/j.alcr.2019.03.003.

\section{References}

Babel, J. (2018). Transitions après un titre du degré secondaire II et intégration sur le marché du travail. Bern: Swiss Federal Office of Statistics.

Babel, J. (2019). Évolution démographique et conséquences pour l'ensemble du domaine de la formation. Bern: Swiss Federal Office of Statistics.

Becker, G. S. (1964). Human capital theory. New York: Columbia University Press.

Bol, T., \& van de Werfhorst, H. (2011). Educational systems and the trade-off between labour market allocation and equality of educational opportunities. Comparative Education Review, 57(2), 285-308.

Brandt, M., \& Hank, K. (2014). Scars that will not disappear: Long-term associations between early and later life unemployment under different welfare regimes. Journal of Social Policy, 43(4), 727-743.

Breen, R., \& Goldthorpe, J. H. (1997). Explaining educational differentials: Towards a formal rational action theory. Rationality and Society, 9(3), 275-305.

Brunello, G., \& Rocco, L. (2017). The labour market effects of academic and vocational education over the life cycle: Evidence based on a British cohort. Journal of Human Capital, 11(1), 106-166.

Card, D. (1999). The causal effect of education on earnings. Handbook of labor economics, Vol. 3, Elsevier1801-1863.

Dearden, L., McIntosh, S., Myck, M., \& Vignoles, A. (2002). The returns to academic and vocational qualifications in Britain. Bulletin of Economic Research, 54(3), 249-274.

Dionisius, R., Muehlemann, S., Pfeifer, H., Walden, G., Wenzelmann, F., \& Wolter, S. C. (2009). Cost and benefit of apprenticeship training - A comparison of Germany and Switzerland. Applied Economics Quarterly, 55(1), 7-37.

DiPrete, T. A., \& Eirich, G. M. (2006). Cumulative advantage as a mechanism for inequality: A review of theoretical and empirical developments. Annual Review of Sociology, 32, 271-297.

Estévez-Abe, M. (2005). Gender bias in skills and social policies: The varieties of capitalism perspective on sex segregation. Social Politics: International Studies in Gender, State \& Society, 12(2), 180-215.

Firebaugh, G. (2008). Seven rules for social research. Princeton: Princeton University Press.

Forster, A., Bol, T., \& Van de Werfhorst, H. G. (2016). Vocational education and employment over the life-cycle. Sociological Science, 3, 473-494.

Gangl, M. (2006). Scar effects of unemployment: An assessment of institutional complementarities. American Sociological Review, 71(6), 986-1013.

Grønning, M., Kriesi, I., \& Sacchi, S. (2018). Institutional Dimensions of Swiss VET: Measures of standardization, differentiation and vocational specificity in Swiss upper secondary vocational education and training. Working paper. Zollikofen: Swiss Federal Institute for Vocational Education and Training.

Hanushek, E. A., Schwerdt, G., Woessmann, L., \& Zhang, L. (2017). General education, vocational education, and labour-market outcomes over the life-cycle. Journal of Human Resources, 11(1), 52-87.

Hoffman, N., \& Schwartz, R. (2015). Gold standard: The Swiss yocational education and training system. Washington, DC: National Center on Education and the Economy.

Korber, M. (2019). The labour market returns to vocational education over the life course (Ph.D. dissertation)Lausanne: University of Lausanne.
Luijkx, R., \& Wolbers, M. H. J. (2009). The effects of non-employment in early work-life on subsequent employment chances of individuals in The Netherlands. European Sociological Review, 6(1), 647-660.

Malamud, O., \& Pop-Eleches, C. (2010). General education versus vocational training: Evidence from an economy in transition. Review of Economics and Statistics, 92(1), 43-60.

Meer, J. (2007). Evidence on the returns to secondary vocational education. Economics of Education Review, 26(5), 559-573.

Meyer, T. (2009). Can 'vocationalisation' of education go too far? The case of Switzerland. European Journal of Vocational Training, 46(1), 28-40.

Moffitt, R. A. (1999). New developments in econometric methods for labor market analysis. Handbook of labor economics, Vol. 3, Elsevier1367-1397.

Müller, B., \& Schweri, J. (2015). How specific is apprenticeship training? Evidence from inter-firm and occupational mobility after graduation. Oxford Economic Papers, 67(4), 1057-1077.

Müller, W., \& Gangl, M. (2003). Transitions from education to work in Europe - The integration of youth into EU labour markets. Oxford: Oxford University Press.

Murphy, E., \& Oesch, D. (2016). The feminization of occupations and change in wages: A panel analysis of Britain, Germany, and Switzerland. Social Forces, 94(3), 1221-1255.

OECD (2010). Learning for jobs: Synthesis report of the OECD reviews of vocational education and trainingParis: OECD.

OECD (2013). A skills beyond school review of Switzerland. Paris: OECD.

Oesch, D. (2013). Occupational change in Europe. How technology and education transform the job structure. Oxford: Oxford University Press.

Protsch, P., \& Solga, H. (2015). How employers use signals of cognitive and noncognitive skills at labour market entry: Insights from field experiments. European Sociological Review, 31(5), 521-532.

Shavit, Y., \& Müller, W. (1998). From school to work: A comparative study of educational qualifications and occupational destinations. Oxford: Clarendon.

Stalder, B. E. (2011). Das intellektuelle Anforderungsniveau beruflicher Grundbildungen in der Schweiz. Ratings der Jahre 1999-2005. Basel: Institut für Soziologie der Universität Basel/TREE.

Tillmann, R., Voorpostel, M., Kuhn, U., et al. (2016). The Swiss household panel study: Observing social change since 1999. Longitudinal and Life Course Studies, 7(1), 64-78.

Weber, S. (2014). Human capital depreciation and education level. International Journal of Manpower, 35(5), 613-642.

Winkelmann, R. (1996). Employment prospects and skill acquisition of apprenticeshiptrained workers in Germany. Industrial and Labour Relations Review, 49(4), 658-672.

Winkelmann, R. (2006). Qualifikationsspezifische Beschäftigungsperspektiven und berufliche Flexibilität. In A. Frick, \& A. Wirz (Eds.). Berufsbildungsökonomie: Stand und offene Fragen (pp. 75-105). Bern: hep Verlag.

Wolter, S. C., Cattaneo, M. A., Denzler, A., Diem, A., Grossenbacher, S., \& Hof, S. (2014). Swiss Education Report 2014Aarau: Swiss Coordination Centre for Research in Education (SKBF/CSRE).

Wolter, S. C., \& Ryan, P. (2011). In R. Hanushek, S. Machin, \& L. Woessman (Vol. Eds.), Handbook of the economics of education: Vol. 3, (pp. 521-556). Amsterdam: Elsevier. 